\title{
SHOULD FEMINISTS STOP TALKING ABOUT CULTURE IN THE CONTEXT OF VIOLENCE AGAINST MUSLIM WOMEN? THE CASE OF "HONOUR KILLING"
}

\begin{abstract}
Sherene H. Razack
Abstract: The violence, scale, and power of anti-Muslim narratives circulated on the internet and elsewhere continue to have considerable impact on feminist antiviolence initiatives. I examine contemporary responses to "honour killings" with particular reference to the Palestinian, Indian, and North American contexts, reflecting on how anti-violence advocates negotiate the terrain of culture in the case of honour killings. I ask whether the focus on culture has an impact on how courts and society view violence committed by Muslim men (and sometimes women) against Muslim women and girls. I suggest that cultural details contribute little to an enhanced legal understanding of the crime simply because this is not their primary purpose. Instead, the cultural details are part of a pedagogy that conveys a message of the racial and cultural superiority of the dominant society and a corresponding inferiority of Muslim cultures. We should therefore always talk culture with the greatest of restraint lest the racism that accompanies culture talk inhibit our understanding of the violence and limit our capacity to respond to it.
\end{abstract}

Keywords: honour killings, anti-violence initiatives, race, culture

Sherene H. Razack PhD is Distinguished Professor and Penny Kanner Endowed Chair at the University of California at Los Angeles, Department of Gender Studies, Box 951504, 1120 Rolfe Hall, Los Angeles, CA 90095-1504. Email: sherenerazack@ucla.edu 
International Journal of Child, Youth and Family Studies (2021) 12(1): 31-48

This article considers the question "Should feminists stop talking about culture?" in cases of violence against Muslim women. Although I have been wary of "culture talk" for some time, and not just in the context of Muslim women, the question is particularly pertinent with respect to Muslim women in view of the widespread marking of Muslim cultures as more patriarchal and violent towards women than other cultures. Practices that are associated with some Muslim communities, such as forced marriages, honour killing, and compulsory veiling, are often regarded as religious in origin and a feature of Muslim life everywhere. The marking of Islam and Muslims as barbaric has considerable geopolitical resonance, installing a colour line where Islam stands as the antonym to Western modernity. Feminists concerned with violence against women are often divided on the question of what violence has to do with culture. To consider culture is often to fall headlong into the racist argument that Muslims are barbaric. On the other hand, it is difficult to avoid culture talk altogether, not only because there is such an appetite for anti-Muslim racism but because it is necessary to consider the culturally specific ways in which violence against women occurs if we are to devise effective anti-violence strategies. In what follows, I attempt to thread my way through the culture debates of the past few decades, beginning with my own work to identify where the difficulties lie in talking culture before turning to feminist considerations of honour killings in Palestine and India, and finally to Canada.

\section{The Culturalization of Violence}

In Looking White People in the Eye (1998), I showed that violence against racialized women (including Indigenous women) was repeatedly culturalized in the courts and in other contexts: that is, the violence was attributed to the extreme patriarchies of non-European cultures. A focus on culture has the effect of producing White men as better than other men - as less patriarchal, or not patriarchal at all — and obscuring the fact that White women encounter considerable violence from White men. Importantly, cultural explanations work to obscure colonialism or White supremacy. Racialized women become objects to be saved, typically by White women. As racialized women, our role in this scenario is to assist the state and White anti-violence professionals and activists with understanding our own violent cultures, thus serving a sort of native informant role that is often the only one available to us. Even those of us writing about culture from an anti-racist perspective often can only enter the fray as native informants of some kind (Razack, 2000, 2001). Our native informant role affects how we understand violence in our own communities, leading us to focus on cultural specificities at the expense of other factors.

In ongoing work on violence against racialized women, I asked, "What gives narratives of sexual violence against South Asian women their power in the West?" and found that the answer was always the same: a full-blown Orientalism. South Asian feminists were themselves telling a codified story about violence that mimicked the colonial one. That is, we told a story of our tribal, premodern culture full of abusive husbands, fathers, and mothers-in-law as inherently violent and argued that South Asian women had to be assisted to live the free, autonomous, lives of our White 
sisters. It seemed that we could find no other frame for our stories of violence. When we tried to tell a more complicated story of violence, we could not easily strip away the allure of exotic details, such as the burning of women with hot oil. Such culturally specific details made the harm vivid but provided only part of the story. Films about violence against South Asian women, for example, often chose the cultural lens, weaving exotic images into a story of culturalized violence and neglecting to consider how racism affected the story of violence. Saris blowing in the breeze provided a more memorable image than White men in suits making immigration laws (Razack, 2003).

In the post 9/11 period, when Muslim communities are widely stigmatized and under surveillance, discussions of violence against racialized women are overdetermined by the figure of the Muslim, something I wrote about in Casting Out (2008). I began to see that I had to think more about neoliberal and racial governmentality, tracking how new modes of governance, and the subjectivities they produced and sustained, relied upon the narrative of saving Muslim women from their men and communities. Muslim women's stories about violence are getting harder to tell since they give so much grist for the mill of anti-Muslim racism and indeed, for anti-Muslim wars and military occupations.

Below I offer two contemporary examples of discussions of violence against racialized women. These examples, from Palestine and India, involve racialized groups telling their own stories of violence against women as originating in culture. As will become clear, to culturalize violence against women is to foster a global regulation of racialized societies through the idea that such societies are deeply patriarchal and require the guidance of the West, and sometimes bombs, to enter modernity. The story of the West as civilized versus the East as barbaric travels to nonWestern societies where those who view themselves as more secular and modern than their "tribal" counterparts are able to produce themselves as modern through the bodies of women who encounter patriarchal violence. Although these accounts from the East appear to be an internal discussion about violence against women they are in fact transnational discourses, as I show below, that maintain the characterization of the West as civilized and the non-West as barbaric through the idea of Muslims as exceptionally violent towards women.

\section{Attitudes Towards Honour Killing: A Middle Eastern Example}

In November of 2012, the Palestinian rap group DAM released a music video on the topic of honour killing (DAM, 2012). The video depicts the story of a young woman who is murdered by her brother and father and then buried. As Abunimah (2012) reported in the Electronic Intifada, the video has a specific legal context: in the Occupied Territories, legal provisions that treated perpetrators of honour crimes leniently had been officially cancelled in 2011; however, DAM asserted that the decree imposing the cancellation was not being effectively enforced (para. 3). Abunimah stated that between 2004 and 2006 in the occupied territories there were 32 cases of "honour killing"; in 2009, there were 13. Abunimah speculated that harsh economic and social conditions contributed to violence against women. DAM maintained that they wanted to protest 
International Journal of Child, Youth and Family Studies (2021) 12(1): 31-48

lenient laws about honour killing wherever they existed in the Arab world, and most of all they wanted to send a message to all Arab communities that killing women was not acceptable (Abunimah, 2012). The video was funded by the United Nations Entity for Gender Equality and the Empowerment of Women, which promoted it enthusiastically.

It is instructive to examine internet responses to the DAM video. While fans of DAM congratulated the group that Palestinian men were at last taking on the issue of violence against women, others criticized DAM for showing Palestinian women as lacking in agency and as desiring individual freedom, especially the freedom to have things. Noting that the video came at a time of the fierce attack on Gaza, two professors at New York's Columbia University, Abu Lughod and Mikdashi (2012), suggested that DAM seemed to have forgotten "the gritty and complex realities of life on the ground in the places they know" (para. 3). The two scholars charged that the video "operates in a total political, legal, and historical vacuum" (para. 5). They also stated that, in offering such a simplistic analysis of honour killings, DAM had succumbed "to an international anti-politics machine that blames only tradition for the intractability of (some) people's problems" (para. 3). Other critics, such as Nadera Shalhoub-Kevorkian and Suhad DaherNashif (2012), argued that feminists should not assist the state to culturalize violence. They reported that their research in colonized Palestinian society showed that insisting that the violence is about culture makes it hard to enlist family and community in anti-violence strategies on the ground in Israel. Further, within Israel, Palestinian women cannot count on the state for help. There are few shelters or Arabic-speaking police or community workers, and the police often support the most patriarchal segments of the community. Providing specific examples of effective antiviolence strategies developed by Palestinian women's groups themselves, they make clear that an approach that demonizes the community not only promotes racism, but does little to solve the problem of violence.

Nafar, Nafar, and Jrery (2012), the members of DAM, rejected two main points of the argument advanced by Abu Lughod and Mikdashi (2012). First, Israeli colonialism is not relevant to a consideration of honour killings because they also happen in places outside Israel and in noncolonized parts of the Arab world. Second, to address what DAM clearly views as a problem internal to Arab society, it is not necessary to consider how the non-Arab world will react. As DAM insisted, "When we write songs, we do not sit and think, "What would America or Israel think of this?" (para. 4). Indeed, they felt it was especially crucial then, at the time of the Arab Spring, for Arab societies to "dispense with concerns over how we may be read (particularly by the West)" (para. 12) and to turn their critical gaze inwards. They rejected the idea that UN sponsorship had influenced their message. As they put it: "DAM is addressing an Arab audience in Arabic. We can speak to our own communities without being worried about how others will abuse it" (para. 9).

As this exchange reveals, the discussion about honour killings turns on culture versus context. On one side are those who maintain that the political, social, and historical context is important because we must examine what enables patriarchal violence to thrive, and what might help to end 
International Journal of Child, Youth and Family Studies (2021) 12(1): 31-48

it. This side also stresses that culturalizing the violence causes racism and colonialism to thrive. On the opposite side are those who insist that culture and tradition are the culprits and that the best way to challenge the source of the violence is to focus on them exclusively. Those who take this latter position, as DAM did, do not regard it as necessary to consider the wider conditions of communication and what others might think outside the Arab world. It is noteworthy that in this view the internal and the external are neatly separated. What is foreclosed is the possibility that honour killing is also a narrative that circulates, producing along the way modern and premodern subjects and doing specific political work both internally and externally.

DAM explicitly refused to consider how the United Nations functions as a mode of governance and thus how a seemingly unexceptionable goal - exposing violent Muslim men and helping imperilled Muslim women — is also part of a governmentality (Nafar, Nafar, \& Jrery, 2012). The group seemed to have not considered the work of feminists who have shown how the empowerment of women and the improvement of their lives are manipulated by governments. For example, one way this is achieved is through the idea that strengthening civil society in the Middle East requires teaching women how to deal with their violent men. "The focus on civil society", Zakia Salime (2011) wrote, "aims in fact to diminish the role of political players, notably the Islamist dissent" (p. 226); it requires that women be portrayed as victims of tradition and invites reformers to separate good Muslims from bad Muslims, with the latter then becoming objects of state surveillance. As Abu-Lughod and Mikdashi (2012) noted, the abstraction of women from their social, political, and historical contexts fragments Palestinian society and purges it of ongoing colonial struggle. Salime (2011) further noted that feminists who ignore the vital role of civil society as a site of neoliberal governmentality, and as impetus for initiatives like the U.S. War on Terror, become part of this mode of governance. Our task as feminists is to consider how to avoid this effect as we pursue anti-violence strategies.

\section{The Honour Killing Narrative in India}

Inderpal Grewal (2014) offered an Indian example of how the honour killing narrative behaves as a travelling narrative. Grewal's article locates the honour killing narrative in Western anthropology where it first referred to a form of masculine power that is based on reputation. The term came to characterize traditional societies as opposed to modern ones, and was linked to the subordination of women and, ultimately, to violence against women. Muslim cultures receive a disproportionate share of attention in this regard. Importantly, Grewal showed that in one set of arguments by Western scholars, Muslim cultures are presumed to be unchanging: even when Muslims become part of the diaspora, they are seen as remaining faithful to the concept of honour and all its attendant effects for women. However much they vary in detail, honour killing narratives have in common the notion that "modern" societies are not honour societies. White North American violence against women cannot therefore ever be described as having to do with notions of honour. Patriarchy, Grewal concluded, has been "outsourced" to the premodern non-West; Western violence against women is blamed on individual behaviour, not on culture. 
Honour as a crime of culture rather than a crime of patriarchy has a specific trajectory in contemporary media accounts. The patriarchy from which it comes is generally assumed to be non-Western, with some exceptions such as Italy (Giuffrida, 2019) where the honour crime narrative has also circulated. It is rare that Europeans are considered to engage in honour killing and any examples are taken to indicate the last vestiges of a culture that has already modernized and moved beyond its tribal past. As in the DAM video, the archetypical honour-killing scenario requires a young woman who wants to be modern in conflict with a patriarchal, traditional family (Abu Lughod \& Mikdashi, 2012; Grewal, 2014). Feminists, no less than other commentators, participate in the circulation of the narratives of honour killing as a crime of culture. What work does the honour narrative do in India? Grewal (2014) reported that newspapers in Delhi were full of stories of honour killing (using that term), typically involving young people or women murdered for crossing caste lines to marry. Interestingly, Grewal found that articles about honour killing had increased dramatically over the previous decade. Prior to 2005 , very few publications referred to honour killing when violence against women was discussed. Grewal urged us to examine the role of the media in order to understand the work that the honour killing narrative does in the non-West. (The fact that the Indian media use the specific term "honour killing" reveals the Western origins of the narrative.) In India, the honour narrative marks the distinction between a modern, enlightened India and a tribal, premodern Pakistan or the India of rural patriarchy and poverty; in this narrative, patriarchy is "outsourced" to Pakistan and to rural areas and is thought not to be a feature of modern India. The narrative also takes on the gloss given to it by Hindu nationalist groups to foment anti-Muslim hate by accusing Muslim men of luring Hindu girls (Grewal, 2014).

The role of law in the honour crime narrative is revealing: Grewal (2014) pointed out that there is a call for special penalties for honour killing but not for rape. One important repercussion of the focus on honour killing is the lack of attention to economic and property issues as part of the context of the killing. As Grewal (2014) stated:

Neither the legislature nor the courts are anxious to deal with these questions of property and rights, so that "honor killings" and the outrage expressed against the media, remains a way to increase the power of the media and the law and order apparatus through new legal statutes rather than addressing the ways in which violence takes multiple forms. (p. 184)

I am particular taken with Grewal's (2014) closing argument:

For violence that is ongoing, caused by multiple factors and their convergences, honor killings produce an easy upper caste and class and racial and developmental answer to the crime. Viewer becomes detective in the Western television genre of the crime show, or the police, in the Bombay cinema tradition, and particular cultures are criminalized in order to bring closure to the crime. (p. 185) 
International Journal of Child, Youth and Family Studies (2021) 12(1): 31-48

I like the image of honour crime reportage inviting the public into a crime show drama. Here the honour crime serves as lurid entertainment. We need to think seriously of the way in which stories of honour killing produce a rush of superiority, precisely the kind of "frisson" I described happening in European debates about honour killings (Razack, 2008, pp. 107-144). In the Canadian context, which I discuss below, the cultural narrative produces Whites as civilized and non-Whites as barbaric. Whites feel a similar excitement about their own superiority as nonMuslim urban Indians do in Grewal's example.

\section{Honour Killing in Canada: Two Examples}

In December of 2007, in Toronto, Canada, 16-year-old Aqsa Pervez was killed by her 57-yearold father, a taxi driver originally from Pakistan. The media concluded that Aqsa had been killed because she refused to wear the hijab and this detail quickly drew the public to the conclusion that "Islam did it". Indeed, two feminist scholars of Muslim origin articulated this position: Haideh Moghissi and Sharzad Mojab (2008) suggested that Pervez's death was due to "religious justification [and] Islamic moral codes of conduct" (para. 3), and attributed the influence of "imported orthodox Imams" (para. 6) to a Canadian multiculturalism that permits "cultural ghettos" (para. 4). Their line of argument here is an uncomplicated one that concludes that governments should be alert to the risks of listening to conservative voices in Muslim populations and should find ways to weed out religious extremism.

Other feminist scholars however, resisted a cultural narrative and insisted that context matters a great deal in this case, and that religion and culture could not be understood outside of social, political, and historical contexts. In an article published in 2010, Eve Haque argued that, as a member of a second or "homegrown" generation, Aqsa provoked national anxieties about Canada as a tolerant multicultural nation. These anxieties were resolved in the media through a presentation of Aqsa's murder as the result of Muslim failure to integrate into the modern, tolerant, enlightened nation of Canada, while Aqsa's father was seen as having returned our kindness with cruelty and violence. Haque showed how Canadians were tutored in the belief that they were a civilized nation betrayed by an unscrupulous Muslim migrant whom they had generously taken in.

As part of her argument that a cultural argument facilitates racism, Haque (2010) reported that the media made frequent use of photos from Aqsa's Facebook page showing a teenager in full makeup who sometimes wore a hoodie;media accounts emphasized that Aqsa "just wanted her freedom" and "led a double life" between her patriarchal family and a more enlightened Canadian community (Haque, p. 86). The media turned to researchers of colour who reported that teenaged

girls such as Aqsa often feel split between modern and traditional cultures and only long to fit in (Haque, p. 88). Some columnists, such as Italian Canadian Rosie DiManno of the Toronto Star, recalled their own strict fathers and how, in an earlier time, given their fathers' religious beliefs, they too would have been beaten for dressing the way that Aqsa did; they portrayed their cultures as having emerged into modernity while Muslim cultures had not (Haque, p. 92). 
Haque (2010) mined the media accounts for details that might interrupt this simple cultural story. She found that Aqsa's family of 11 led an impoverished life, all living in one apartment. She reported claims by shelter workers that minority girls and women had difficulty accessing shelter services owing to racism, and that such services were badly underfunded; indeed, many health care services were cut altogether, as were immigrant services in general, including employment, mental health, and family counselling. Haque pointed out that Aqsa's teachers knew that she often had bruises on her arm but did not report the possibility of child abuse. Few observers asked the teachers what they had tried to do and why their efforts failed.

At the time she was killed, immigrant communities like the one to which Aqsa belonged were experiencing heightened racism and surveillance along with severe economic marginalization, and, significantly, in contradiction to arguments about integration, the second generation was faring even worse than the first: these are conditions in which patriarchies thrive (Haque, 2010). It is certain that the media's emphasis on Canada as a multicultural haven with a culture that Aqsa desired to explore ignores a seamier side of immigrant reality, a reality that should push us to question what really produced Aqsa's tragic situation. Instead of understanding Aqsa as merely trapped in her culture, we have to imagine her, her family, and her community negotiating migration, culture, school, and nation. In this framework, Aqsa is an active agent who creatively negotiated the dress codes and norms of her social group in school; to reach her, we would have had to appreciate this wider context, resisting the urge to linger on her culture and instead exploring the many places of stress in her life and how she might have been helped at multiple sites in multiple ways. In its emphasis on context rather than culture, Haque's analysis parallels the one offered by Abu Lughod and Mikdashi (2012) for the Palestinian situation.

As compelling as the analyses of Haque (2010) and Abu Lughod and Mikdashi (2012) are, (and these are analyses that once aligned with my own), they share an important elision: it is hard to find the extremely violent father in the above accounts, and even harder to find his religion, culture, and community. Put another way, we see racism more easily than we see patriarchal violence. I believe that feminist analysis that stresses the social, political, and the historic has to find a place for ultraviolent men and families, a place that neither exceptionalizes nor exonerates them. This is not only so that we do not leave the impression that such men ought to be exonerated but, more importantly, so that we are able to examine what strategies would be effective for dealing with violent, ultra-patriarchal men. How to achieve these goals is unclear, but a promising direction that I outline below is to consider what role culture plays in anti-violence work and service provision in comparison to the role it plays in the courts. Here it is crucial to note that Canadian courts have dealt quite well with recent cases of violence against women in which culture has been raised as an issue, as discussed below in the case of the Shafia murders. The perpetrators received life sentences. The issue is not, therefore, one of leniency. 
International Journal of Child, Youth and Family Studies (2021) 12(1): 31-48

\section{The Shafia Killings}

Those of us who shared Haque's (2010) analysis about the stresses placed on poor immigrant families received a shocking comeuppance when an even more horrific "honour killing" occurred, this time in a family where poverty was not an issue. The wealthy Shafia family, originally from Afghanistan, emigrated to Montreal, Canada in 2007 under the investor program. The new arrivals included businessman Mohammad Shafia, his second wife, Tooba Mohammad Yahya, their daughters Zainab, Sahar, and Geeti, their son Hamed, and three other children; first wife Rona Muhammad Omar joined them a few months later. In 2009, Mohammed Shafia, together with his eldest son and second wife, premeditatedly murdered his three teenaged daughters and his first wife (whom he had been passing off as his cousin). Shafia appeared to believe that the three girls had dishonoured him by having boyfriends.

It is hard to fit Shafia into the scenario described by Haque (2010). In an exhaustive account of the crime, the journalist Michael Friscolanti (2012a, 2012b) reported that Shafia was not poor and did not seem particularly religious. Indeed, Shafia described himself as a target of the Taliban because his family was a liberal one. He did not impose the veil on his family; the girls' styled hair and make-up ironically helped to persuade school authorities that they were not at risk from a Muslim fundamentalist patriarch. Shafia did, however, often express views about honour and had on more than one occasion demanded the kind of obedience and control common to violent patriarchs of all cultures. In a wiretap, he can be heard saying of his dead daughters, "May the devil shit on their graves", a comment he explained as a reaction to seeing revealing photographs of his daughters for the first time (Friscolanti, 2012a). Not surprisingly, the Shafia killings led to a racial media spectacle (see, e.g., the books of journalists Schliesmann, 2012 and Tripp, 2012). Schliesmann (2012) concluded that the Shafias, and in particular Mohammed Shafia, "were clearly not prepared to adapt to the secular society they were living in" (p. 59).

\section{Service Provision in the Shafia Case}

The Shafia girls tried to get help, from strangers, social services, police, and school authorities: all made attempts to help the girls. Notably, the first wife had few options for seeking help because the Shafias held her passport and she had no direct contact with Canadian society. The police, teachers, and social workers who knew of the difficulties in the family seem to have been puzzled by the situation and were not able to determine what could be done about it. What might have stopped Shafia, his son, and his wife from carrying out the murders? How could the victims have been protected? Authorities were seriously impeded when the girls retracted their statements, as victims often do. One wonders why these professionals seemed not to consider two classic features of family violence - that the stories victims tell in the presence of the abuser differ from those they tell when the abuser is not around, and that spouses and family members are often complicit in the abuse. Would better training in overall violence prevention have helped? Or should more Afghan-specific strategies have been developed? What should these professionals have known about aspects of Afghan culture? 
For well over a decade, Mojab (2012) has argued strongly that it is necessary to focus on culture. In making her argument, Mojab returned to a point often made in her work, accusing postmodern feminists of practising a cultural relativism when they insist on posing questions about the context in which culture unfolds. Rejecting the idea that honour killing should be understood in the same vein as domestic violence, Mojab argued that it is important to understand the special cultural features of honour killings in order to develop early warning systems that alert us to the possibility that an honour-based crime may be impending. One challenge in keeping culture uppermost is the difficulty of holding both cultural difference and the sameness of patriarchal violence in one's analysis. The cultural angle seems to inhibit hard thinking about the nature of violence against women and girls, dulling feminist impulses honed over several decades of antiviolence initiatives. Feminists should know, for instance, that powerful, controlling men have more opportunities to commit violence against women with impunity than do less powerful men. We also tend to absolve the state when culture is our focus, never critically examining its role in the Shafia case, whether at the site of law or service provision. I suggest that the power of the cultural difference narrative blocks critical thinking. Affectively, it invites us to feel superior rather than to think critically. This affective state also discourages service providers and institutions from asking the question, "What do I know and not know about a particular cultural context, given my own subject position?"

\section{The Trial: What's Culture Got to Do with It?}

Amidst these details, is there a case for feminists to talk culture and honour killing and, if so, where should this be done, and to what end? In the Shafia case, the prosecution applied to admit expert evidence on culture into the trial, arguing that the motive for the murders was the preservation of the family's notion of honour. The prosecution further argued that to understand motive the court would benefit from the help of Dr. Shahrzad Mojab, who had studied honour killing in Turkey and Iran and who could speak to the relationship between culture, religion, patriarchy, and violence against women.

As stated in Her Majesty the Queen v. Shafia (2012), when considering the Crown's application to allow the expert evidence of Dr. Mojab, Justice R. L. Maranger drew on case law to say that Dr. Mojab would be able to provide the court with "evidence of a phenomenon that exists in a foreign culture" (p. 4). In pretrial hearings, the court heard testimony from wiretapped conversations where Mohammed Shafia was heard denouncing his daughters as "treacherous" and saying that "nothing was more dear to me than my honour" (p. 6). Despite the risk that a jury provided with expert testimony will rely on it to the point of abdicating its own fact-finding role, in this case, the judge declared that evidence about honour in certain societies would help the court to understand why the Shafias acted as they did, stating: "The concepts of honour, family and gender dynamics within Middle Eastern and East Asian communities is knowledge that is outside the scope of a typical Canadian jury" (p. 7). The defence argued that Dr. Mojab was biased since she was a committed feminist, an argument the judge rejected. When the defence followed up by arguing that Mojab's evidence would in fact be an argument for seeing the crime as an honour 
International Journal of Child, Youth and Family Studies (2021) 12(1): 31-48

killing, the judge agreed and ruled that Dr. Mojab's testimony be limited to the generic. She would not be allowed to discuss the specifics of the Shafia case.

As we can see, from the beginning, expert testimony about honour killing is assumed to be testimony that would help a Canadian court to understand foreignness, a frame that makes it hard to dislodge the culturalizing of violence and the making of the colour line. Mojab herself has written of her realization after the fact that her testimony produced this effect. In an article published in 2012, Mojab wondered what the jury actually learned from her testimony:

Reflecting on my experience, I remain doubtful of the success of my educational and advocacy roles in explicating the complexity of honour crimes within the court setting. Through the process of testifying and cross examination, my intellect was culturalized; my Iranian origin - my shared language and culture with the perpetrators - became more prominent than my knowledge of the topic. (Mojab, 2012, p. 119)

Her shared culture with the perpetrators was used to undermine her expert status even as the defence sought to show that she did not know anything about Afghan culture, having done her research on the Kurdish community in Turkey and Iran, and not in Afghanistan. The undue emphasis on culture, she concluded, "potentially contributes to the culturalization of the honour crime; it primordializes, stigmatizes, and demonizes the community, and eventually contributes to outright racism" (Mojab, 2012, p. 119).

After the trial, Mojab continued to fight the racism that is a usual feature of honour killing discourses. In December 2011, she published a short article relating that while she was on the witness stand the Crown asked her to read a passage from a United Nations Commission report that was openly racist (it described an Arab proverb that "a man's honour lies between the legs of a woman"). Mojab noted that the media took these to be her own words, and she felt compelled to distance herself from the assumption, reiterating that honour has nothing to do with Arabness.

The Shafia case, and Mojab's reflections above, raise an important consideration: Is "talking culture" in a courtroom doing the same work as "talking culture" with respect to service provision? Without the cultural details, could the court have understood and appropriately condemned the killings? My response is a cautious yes. I am encouraged by a criminal lawyer who noted that the Shafia trial was a standard run-of-the-mill murder trial (Frank Pappas, quoted in Monique Muise, 2012). The cultural details were unimportant given the overwhelming evidence that brutal murders had been committed.

\section{Law Provides a "Tryst"}

What, then, is the work that the honour killing narrative is doing in the Shafia trial? I suggest that in a criminal trial of this sort, the cultural details contribute little to an enhanced legal understanding of the crime; indeed, this is not their primary purpose. Instead, the cultural details 
are really part of a pedagogy, intending to convey to Canadians a message of their racial and cultural superiority with respect to the accused. The media collaborates in this endeavour, as Grewal (2014) showed for India and as Dana Olwan (2013) has shown for the Shafia trials. Inside the courtroom, the privileged status of jurors, lawyers, and judges, who are often steeped in an understanding of Muslim cultures as barbaric and are likely to be operating with a culturalist understanding of violence, is reinforced by the racial thrust of the honour crime message; culture talk simultaneously creates two types of subject: superior White or White-aspiring subjects whose national belonging is confirmed, and abject racial or cultural others who are outsiders to the nation. In the courtroom context, the latter group includes not just defendants in honour killing cases, but experts on culture, as Mojab recalled of her own experience. Law must be understood in this context as providing what Anthony Farley (1997) so accurately described as "the tryst", whereby a White public can consummate its longing for Black humiliation. Feminists calculating the conditions of communication need to keep a close watch on the production of the colour line, especially its affective dimensions.

Crown attorney Laurie Lacelle explained to the jury that the four victims simply wanted their freedom, which Shafia withheld from them (Friscolanti, 2012a, p. 40). The idea of honour would have bolstered this argument but was not necessary; without it, the case could have certainly been made that Shafia was an extremely controlling man, even able to control his son and his wife to the point of getting them to collaborate with him in murder. In the end, Justice Maranger sentenced the Shafias to life in prison with no chance of parole for 25 years. Judging from the only quotation from his sentencing remarks that was repeated by journalists, Justice Maranger seemed, however, to rely on the cultural argument:

It's difficult to conceive of a more heinous, more despicable, and more honourless crime.... The apparent reason behind these cold blooded, shameless murders was that the four completely innocent victims offended your twisted notion of honour, a notion of honour that ... has absolutely no place in any civilized society. (Quoted in Blatchford, 2012; see also Friscolanti, 2012b; Greene, 2012; Jiwani et al., 2012)

\section{Getting Out of the Legal Culture Bind}

Reflecting on the Shafia trial, Canadian scholars are increasingly aware of the necessity to consider racism when exploring what culture has to do with violence against women. There is a small but growing scepticism about whether cultural debates should take place in the law at all. In an issue of Criminal Law Review devoted to the Shafia trial, for instance, Anna Korteweg (2012) noted that honour killings are comparatively rare in Canada (10 to 15 cases in a decade, as compared to the 60 women killed per year by partners or ex-partners). Maintaining that we nonetheless need to understand the patterns of violence that lead to honour killing, Korteweg noted that since honour killing becomes a sign of immigrant backwardness we must begin by taking "seriously" the politicization of the crime. Even the invocation of the term "honour killing" conjures racist imaginaries and is therefore problematic from the start. The risks notwithstanding, 
Kortweg advised that we consider honour killing "as a particular form of gendered violence that unfolds at the intersections of gender, race, ethnicity, religion and immigrant receiving societies' cultural, social, political, and legal practices" (Korteweg, 2012, p. 138). Such gendered violence should be considered "part and parcel not of a 'foreign' influence, but of contemporary social life in immigrant-receiving countries" (Korteweg, 2012, p. 138). Immigrant life is not something that can be untangled from foreignness, however, and this is especially true when the immigrants concerned are Muslim. Unless the analysis of contemporary social life includes a focus on how White supremacy operates in all women's lives, Muslim women will simply be seen as the kind of women who suffer from patriarchy more than other women do. As I argued in Looking White People in the Eye, we cannot keep gender abstracted from all other social relations (Razack, 1998, p. 96).

Korteweg (2012) suggested navigating the risk of culture talk by avoiding culture in the courts but considering it in service provision. She proposed that courts should condemn honour crimes using a language of gender inequality rather than a language of cultural difference. For example, a court discussion of the abuse of a child's trust does not need cultural specificity. Korteweg added that we are too drawn to legal answers to the problem of violence; there is often a "misplaced belief in punishment as deterrence and in reified notions of Canadian and, by extension, non-Canadian cultures ... [and] a corresponding disinterest in what happens in non-legal environments" (Korteweg, 2012, p. 159). A second contributor to the Canadian Law Review's special issue on the Shafia trial, Lori Beaman (2012), also insisted on a broad framework of gendered violence, noting that all forms of gendered violence share many similarities, perhaps the strongest argument yet that we have little cause to dwell on the cultural specificities of the violence and the inevitable racism that doing so unleashes. Beaman's (2012) argument is shared by Homa Hoodfar and Yasmin Jiwani (2012), who proposed the use of Shalhoub's term "femicide" rather than "honour killing" to capture the shared terrain with other forms of gendered killing. These scholars have little to say about what we do with the elephant in the room - culture - although their approaches seem to suggest that we should step away from it yet also maintain a pretence that the elephant is not actually there. Sidestepping culture may be difficult to do when there is so much invested in the spectacle of racial inferiority.

\section{Service Provision}

What would strengthen our capacity as feminists to remain fully contextual and to keep a wary eye on White supremacy? It seems clear that law is not the main place to do this work. When we turn to other domains, in particular service provision (police, schools, social work), anti-racism is difficult to operationalize. For example, Fournier, the editor of the special issue on the Shafia trial in Criminal Law Review, noted that all public agencies closed their files on the Shafia children one month before their deaths (Fournier, 2012, p. 111). A major study by the Quebec Human Rights and Youth Rights Commission indicates that "racial profiling and insensitive intervention policies pervade the police and governmental actors in the education system and in the youth protection system" (Fournier, 2012, p. 112). In other words, racism is rife. The study suggested cultural 
International Journal of Child, Youth and Family Studies (2021) 12(1): 31-48

awareness workshops with professionals. However, unless such training were to be entirely enveloped in an anti-racist approach designed to help majority groups examine their own assumptions about themselves and racial Others, it is unlikely that the workshops' focus on culture would be useful. Having been an anti-racist trainer for much of my preacademic life, and noting how discussions of non-Western patriarchal violence seem to result in all workshop participants, both White and non-White moving unthinkingly into the White saviour role, I am sceptical about the value of any training of professionals on issues of culture that lacks a strong anti-racist component.

\section{Conclusion}

In Canada, every five days a woman is killed by an intimate partner and sometimes her children are slain too (Statistics Canada, 2018). Some of these crimes are premeditated and some are not; some involve the complicity or at least the inattention of others and some do not. Perhaps those cultures that live more communally produce the anomaly of the crime having several perpetrators, but this fact changes nothing about who gets killed and how many. We need most of all to ask what is the difference that cultural difference makes and in the asking, we cannot forget the one thing that all patriarchies produce: a proportion of violent, out-of-control men, and sometimes families, who do their killing of women in culturally specific ways.

A small shift in our thinking is all that is needed to change our perspective on honour killing. In the conventional view, a focus on honour pre-empts most other considerations. For example, Sheema Khan (2013), a Muslim journalist who wears the hijab, wrote about the Shafia murders in an article for The Globe and Mail, a Canadian newspaper. In Khan's account of the crime:

1. The women were killed by Shafia "to preserve honour".

2. In Shafia's view, the girls had become "too Western".

3. Honour killings are increasing. (The term as used in the article refers to murders by non-Western immigrants, principally Muslims, and is treated like a disease that they carry with them.)

4. There is a call for a national strategy targeting immigrant communities, a strategy that is in the first instance legal and policy based: "Prevention, Protection and Prosecution".

5. Muslim men and Muslim communities are engaging in anti-violence strategies.

There is another way to frame these events, however. What if the script were changed from the beginning?

1. The women were killed by a violent and controlling father who was able to convince his son and his second wife to be a part of his schemes. 
International Journal of Child, Youth and Family Studies (2021) 12(1): 31-48

2. As new immigrants, the girls did not know where to turn. Their efforts to get help at school or from the police failed owing to a number of factors, some of them bureaucratic and some of them due to racism. Other factors related to how well professionals were trained and able to handle cases of gender violence in general, as well as specifically in minority families with extremely controlling men.

3. We need to consider anti-violence strategies as they concern teachers, social workers, and police. (Once a crime has been committed, the legal system seems to work well.)

4. Immigrant communities need to launch their own anti-violence campaigns.

5. We could craft a national anti-violence strategy that considers how women are killed in a variety of circumstances and identify the multiple sites of violence prevention.

Singling out honour killing in non-White communities seems to be a methodologically unsound decision.

6. As we do all of the above, we need to build critical consciousness of the ways in which power operates, and particularly how subjects are produced through culture talk. In effect, we need to reflect on the production of knowledge and the terms and conditions of communication that leave us with the idea that Muslim cultures are more barbaric and violent than others.

In sum, culture talk often takes us in the direction of racism and away from a more holistic understanding of why women and girls are killed. In all likelihood, feminists cannot stop talking about culture entirely but it would be a good start to abandon the term "honour killing" altogether because it invariably takes us to a place where we consider Muslim cultures to be more violent than others. We would be better able to understand violence and what might prevent it if we refused to indulge in racism and focused more intensely on the pervasiveness of violence against women and on specific strategies to stop violent and controlling men. 
International Journal of Child, Youth and Family Studies (2021) 12(1): 31-48

\section{References}

Abu Lughod, L., \& Mikdashi, M.. (2012, November 23). Tradition and the anti-politics machine: DAM seduced by the 'honor crime'." Jadaliyya . http://www.jadaliyya.com/pages/index/8578/tradition-and-the-anti-politics-machine dam$\underline{\text { seduce }}$

Abunimah, A. (2012, November 6). New DAM hip hop track with video co-directed by Jackie Salloum targets violence against women. Electronic Intifada. http://electronicintifada.net/blogs/ali-abunimah/watch-new-dam-hip-hop-track-video-codirected-jackie-salloum-targets-violence

Beaman, L. G. (2012). The status of women: The report from a civilized society. Canadian Criminal Law Review, 16(2), 223-246.

Blatchford, C. (2012, January 29). No honour in 'cold-blooded, shameless' murder of Shafia girls. The National Post. https://nationalpost.com/opinion/jury-reaches-verdict-in-shafia-trial

DAM. (2012, November 6). If I could go back in time [Video]. YouTube. https://palestine.unwomen.org/en/for-later/videos/dam-video

Farley, A. P. (1997). The black body as fetish object. Oregon Law Review, 76, 457-535.

Fournier, P. (2012). "Introduction: Honour crimes and the law-Public policy in an age of globalization. Canadian Criminal Law Review, 16(2), 103-114.

Friscolanti, M. (2012a). The Shafia honour killing trial: The full story of a crime that shocked the nation. Maclean's Ebook Edition. https://www.macleans.ca/news/canada/inside-the-shafiakillings-that-shocked-a-nation/

Friscolanti, M. (2012b, February 13). A sick notion of honour. Maclean's. http://search.proquest.com/docview/922049192?accountid=14771

Greene, L. (2012, January 30). Polygamist papa 'honor-slays' gals. New York Post. http://search.proquest.com/docview/918658487?accountid=14771

Grewal, I. (2014). Outsourcing patriarchy: Feminist encounters, transnational mediations and the crime of "honor killings". In S. Perera \& S. H. Razack (Eds.), At the limits of justice: Women of colour on terror (pp. 164-190). University of Toronto Press.

Giuffrida, A. (2019, March 18). Italy accused of restoring honour killing defence after lenient femicide rulings. The Guardian. https://www.theguardian.com/world/2019/mar/18/italy-jailterms-reduced-men-killed-wives-femicide 
International Journal of Child, Youth and Family Studies (2021) 12(1): 31-48

Haque, E. (2010). Homegrown, Muslim and other: Tolerance, secularism and the limits of multiculturalism. Social Identities, 16(1), 79-101. doi:10.1080/13504630903465902

Her Majesty the Queen v. Shafia, 2012 ONSC 1538.

Jiwani, Y., Hoodfar, H., \& Dwivedi, S. (2012, January 31). Should we call it 'honour killing'?: NO. It's a false distancing of ourselves from a too-common crime: the murder of females Yes. It is an accurate term for an atrocious act, something we need to recognize and fight. The Montreal Gazette. https://www.pressreader.com/canada/montrealgazette/20120131/281831460623735.

Khan, S. (2013, January 30). Let's work together to prevent crimes of honour. Globe and Mail. https:/www.theglobeandmail.com/opinion/lets-work-together-to-prevent-crimes-of$\underline{\text { honour/article } 7975778 /}$

Korteweg, A. C. (2012). Understanding honour killing and honour-related violence in the immigration context: Implications for the legal profession and beyond. Canadian Criminal Law Review, 16(2), 135-160.

Moghissi, H., \& Mojab, S. (2008, January 9). Of 'cultural' crimes and denials. ZNet. https://zcomm.org/znetarticle/of-cultural-crimes-and-denials-by-haideh-moghissi/

Mojab, S. (2011, December 29). Honour killings and the myth of "Arabness". The Mark News. http://www.themarknews.com/articles/7884-honour-killings-and-the-myth-of-arabness

Mojab, S. (2012). The politics of culture, racism, and nationalism in honour killing. Canadian Criminal Law Review, 16(2), 115-134.

Muise, M. (2012, January 31). Shafia verdict prompts debate. Telegraph-Journal. http://search.proquest.com/docview/918728160?accountid=14771

Nafar, T., Nafar, S., \& Jrery, M. (2012, December 26). DAM responds: On tradition and the antipolitics of the machine. Jadaliyya. http://www.jadaliyya.com/pages/index/9181/damresponds_on-tradition-and-the-anti-politics-of

Olwan, D. M. (2013). Gendered violence, cultural otherness, and honour crimes in Canadian national logics. Journal of Canadian Sociology, 38(4), 533-555.

Razack, S. H. (1998). Looking White people in the eye: Gender, race and culture in courtrooms and classrooms. University of Toronto Press.

Razack, S. H. (2000). Your place or mine: Transnational feminist collaboration. In G. Dei \& A. Calliste (Eds.), Anti-Racism feminism: Critical race and gender studies (pp.39-53). Fernwood Press. 
International Journal of Child, Youth and Family Studies (2021) 12(1): 31-48

Razack, S. H. (2001). Racialized immigrant women as native informants in the academy. In R. Luther, B. Whitmore, \& B. Moreau (Eds.), Seen but not heard: Aboriginal women and women of colour in the academy (pp. 51-60). Canadian Research Institute for the Advancement of Women.

Razack, S. H. (2003). A violent culture or culturalised violence? Feminist narratives of sexual violence against South Asian women. Studies in Practical Philosophy, 3(1), 80-104. doi:10.5840/STUDPRACPHIL2003317

Razack, S. H. (2008). Casting Out: Race and the eviction of Muslims from Western law and politics. University of Toronto Press.

Salime, Z. (2011). Securing the market of war: The Middle East partnership initiative. In S. Feldman, C. Geisler, \& G. A. Menon (Eds.). Accumulating insecurity: Violence and dispossession in the making of everyday life (pp. 215-239). University of Georgia Press.

Schliesmann, P. 2012. Honour on trial. The Shafia murders and the culture of honour killings. Fitzhenry \& Whiteside.

Shalhoub-Kevorkian, N., \& Daher-Nashif, S. (2012, December 17). The politics of killing women in colonized contexts. Jadaliyya. http://www.jadaliyya.com/pages/index/9061/thepolitics-of-killing-women-in-colonized-context

Statistics Canada. (2019). Family violence in Canada: A statistical profile, 2018 (Table 2.2). https://www150.statcan.gc.ca/n1/en/pub/85-002-x/2019001/article/00018eng.pdf?st $=\mathrm{d} 1 \mathrm{cFhGkd}$

Tripp, R. (2012). Without honour. The true story of the Shafia family and the Kingston canal murders. Harper Collins. 